\title{
RISKS OF INDUSTRY 4.0: A THEORETICAL FRAMEWORK FROM SUSTAINABILITY VIEWS
}

\section{RISCOS DA INDÚSTRIA 4.0: UM QUADRO TEÓRICO DOS PONTOS DE VISTA DA SUSTENTABILIDADE}

\author{
R. SOLTOVISKI ${ }^{1}$, T. V. RODRIGUES ${ }^{1, *}$, L. M. M. RESENDE ${ }^{1}$, J. PONTES $^{1}$ and R. T. YOSHINO ${ }^{1}$ \\ ${ }^{1}$ Universidade Tecnológica Federal do Paraná, Department of Production Engineering, Ponta Grossa, Paraná, Brazil
}

${ }^{*}$ Corresponding author. Universidade Tecnológica Federal do Paraná, Department of Production Engineering, Ponta Grossa, Paraná, Brazil, Phone: +55 35 99129-6603

e-mail addressl: thales.volpe@hotmail.com

\begin{tabular}{l} 
A R T I C L E I N F O \\
\hline Article history: \\
Received 2020-11-03 \\
Accepted 2020-12-12 \\
Available online 2020-12-12 \\
p a l avras - ch $a v e$ \\
Indústria 4.0 \\
Gerenciamento de riscos \\
Sustentabilidade \\
Triple bottom line \\
ke y $w o r d s$ \\
Industry 4.0 \\
Risk management \\
Sustainability \\
Triple bottom line
\end{tabular}

\begin{abstract}
A B S T R A C T
Industry 4.0 is a topic little discussed today, especially in relation to the possible negative risks generated by it. In this way, this work aims to raise and discuss the risks of the Fourth Industrial Revolution currently found in the literature from a sustainability perspective and develop a theoretical framework to represent them. For this, a methodology of systematic analysis of the literature was used to relate the relevant works to the theme and thus to discuss them. Two databases (Scopus and Web of Science) were used in which 7772 articles were evaluated, of which 66 were used for the discussion. The 28 risks found were grouped into four dimensions (Economic Risks, Social Risks, Environmental Risks, and Technological Risks) where their relationships were studied and represent in the theoretical framework constructed. In this way, in addition to contributing to the academy building more theoretical contribution to the theme, the risks raised can help managers and companies to checkpoints of attention before implanting technologies and concepts of industry 4.0.

R E S UM O

A indústria 4.0 é um tema pouco discutido hoje, principalmente em relação aos possíveis riscos negativos por ela gerados. Desta forma, este trabalho tem como objetivo levantar e discutir os riscos da Quarta Revolução Industrial encontrados atualmente na literatura sob uma perspectiva da sustentabilidade e desenvolver um referencial teórico para representálos. Para isso, foi utilizada uma metodologia de análise sistemática da literatura para relacionar os trabalhos relevantes ao tema e, assim, discuti-los. Foram utilizadas duas bases de dados (Scopus e Web of Science) nas quais foram avaliados 7.772 artigos, dos quais 66 foram utilizados para a discussão. Os 28 riscos encontrados foram agrupados em quatro dimensões (Riscos Econômicos, Riscos Sociais, Riscos Ambientais e Riscos Tecnológicos) onde suas relações foram estudadas e representadas no framework construído. Dessa forma, além de contribuir para que a academia construa mais contribuições teóricas para o tema, os riscos levantados podem ajudar gestores e empresas a verificações de atenção antes de implantar tecnologias e conceitos da indústria 4.0.
\end{abstract}




\section{INTRODUCTION}

The so-called "industrial revolutions" are characterized by technological leaps capable of changing the productive form (Lasi, Fettke, Kemper, Feld, \& Hoffmann, 2014). The First Industrial Revolution initiated in the late eighteen century introduced mechanical manufacturing systems using water and steam. Begun in the late nineteenth century, the Second Industrial Revolution was characterized by the use of electricity in mass production. In the mid-twentieth century, the Third Industrial Revolution made possible use of automation and microelectronic technology (Xu, $\mathrm{Xu}, \& \mathrm{Li}, 2018)$. In recent years, a change in manufacturing logic with an increasingly decentralized and self-regulating value creation approach through advanced technologies (Internet of Things, CyberPhysical Systems, Autonomous Systems, etc.) that, according to (Zheng et al., 2018), has reduced the boundaries between the physical a virtual world. These changes have been called the "Fourth Industrial Revolution" or "Industry 4.0".

The term "Industry 4.0" arose in Germany from a technology development plan launched in 2011 (Lasi et al., 2014). A few years later, this theme was deepened from a report released in 2013 by Kargerman, Wahlster, and Helbig further discussing the benefits of the new industrial age (Kagermann, Wahlster, \& Helbig, 2013). In Davos in 2016, this term became even more influential at the World Economic Meeting (WEF) with the theme "Mastering the Fourth Industrial Revolution" (Pfeiffer, 2017). In a short time Industry 4.0 began to spread and be discussed by companies, research centers, and universities globally (Bahrin, Othman, Azli, \& Talib, 2016).

In any case, Industry 4.0 has been describing a trend towards the increasing use of information technologies and production environment automation (Kagermann et al., 2013) from a multitude of technologies and concepts (Ahuett-Garza \& Kurfess, 2018) building a digital and interconnected value chain (Lasi et al., 2014).

The use of emerging concepts and technologies from discussions promoted by Industry 4.0 can lead great benefits to companies. However, conceptualizations of the negative impacts of the Fourth Industrial Revolution on the sustainability approach still have little theoretical support. According to (Müller, Kiel, \& Voigt, 2018), Industry 4.0 deployment requires that opportunities outweigh the challenges and risks to be assessed. Thus, studying the possible risks posed by Industry 4.0 technologies and concepts to a whole industrial value chain from a sustainability perspective can help companies be more successful and assertive in adopting these concepts, and governments can be aware of issues that may involve an entire society.

\section{METHODS}

The Methodi Ordinatio developed by (Pagani, Kovaleski, \& Resende, 2015) was applied to survey the articles which were used to discuss the Industry 4.0 risks. This methodology ranks articles based on criteria such as the impact factor of the journals where the articles were published, year of publication, and the number of citations. For this, nine steps are followed as shown in Figure 1.

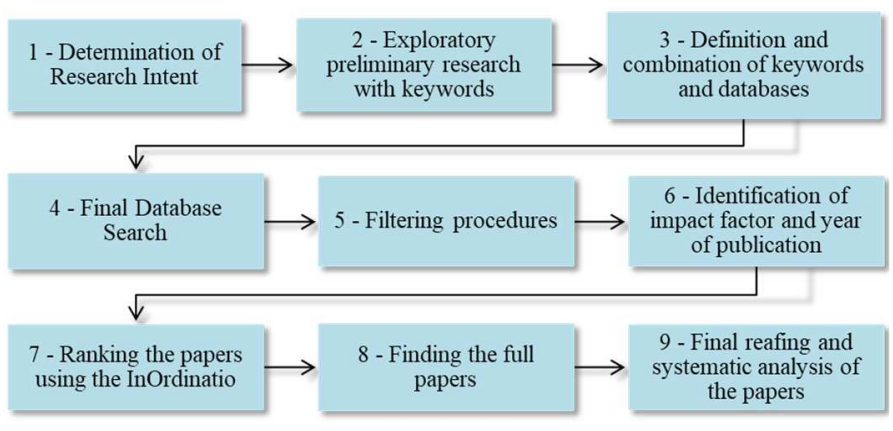

Figure 1 - Steps of Methodi Ordinatio Source: Pagani et al. (2015)

From these steps, two keywords axes ("Industry 4.0" and "risks") were used where each axis was varied in synonyms enabling 72 different combinations as shown in Figure 2. Each combination was verified in two databases (Web of Science and Scopus) from which the articles were extracted.

\begin{tabular}{r|r|}
\hline Industry 4.0 & Risk \\
Industrie 4.0 & Uncertainty \\
Advanced Manufacturing & Uncertainties \\
Industrial Internet & Challenge* \\
Smart Manufacturing & Barrier* \\
Forth Industrial Revolution & Driver* \\
Internet od Everything & Opportunity \\
Industrie du Futur & Opportunities \\
Made-in-China 2025 & \\
\hline
\end{tabular}

Figure 2 - Keyword Combination Demonstration

Thus, 7772 articles were surveyed and subsequently filtered to compose only works within the scope suited. The used filters can be seen in the table below. As shown in Table 1.

Table 1: Filtering Steps

\begin{tabular}{lcc}
\hline Step & $\begin{array}{c}\text { Number of } \\
\text { Excluded Articles }\end{array}$ & $\begin{array}{c}\text { Number of } \\
\text { Remaining Articles }\end{array}$ \\
\hline The gross number of articles & - & 7772 \\
Exclusion of duplicates & 4582 & 3190 \\
Book and book chapters exclusion & 102 & 3088 \\
Filter by Reading titles & 1842 & 1246 \\
Filter by Reading abstracts & 1134 & 112 \\
Filter by Reading the full articles & 46 & 66 \\
\hline Total & & $\mathbf{6 6}$ \\
\hline
\end{tabular}

The articles rank step was not performed due to the study had used all 66 articles in the final portfolio. This rank is better used when there is a need for a criterion of choice among the most relevant works in final the portfolio.

Thus, by reading the 66 final articles, 28 risks were found which are distributed in four dimensions: Economic Risks, Social Risks, Environmental Risks, and Technological Risks. The first three dimensions are based on the concept of sustainability of Elkington's Triple Bottom Line. The fourth dimension is proposed on technological issues. Besides, 11 subdimensions are built to better group the mapped risks. 
Briefly, this distribution can be seen in Appendix A. In the next topic, the risks are discussed according to the authors used for their construction.

\section{INDUSTRY 4.0 RISKS}

\subsection{Economic Risks}

\subsubsection{Financial Risks}

Economic risks may affect the economic sustainability of companies. Within this context, the first challenge encountered is the cost of deploying Industry 4.0. The high degree of complexity in developing a suitable infrastructure for Industry 4.0 implementation can require heavy investment costs (Kamble, Gunasekaran, \& Sharma, 2018; D Kiel, Müller, Arnold, \& Voigt, 2017; Luthra \& Mangla, 2018; Moktadir, Ali, Kusi-Sarpong, \& Shaikh, 2018; Valente, Cotrim, Gasques, Leal, \& Galdamez, 2018) in IT systems, machine parks (Müller, Buliga, \& Voigt, 2018) and skilled labor (D Kiel et al., 2017; Valente et al., 2018). Moreover, according to (G. Li, Hou, \& $\mathrm{Wu}, 2017$ ), for efficient transformation, companies will need to invest not only in current and fixed problems but also for future developments.

There are also uncertainties about the cost-benefit of technologies, where financial returns may not be the expected (Kamble et al., 2018). In the survey by (Müller, Buliga, et al., 2018), respondents comment that investing in Industry 4.0 is costly in the short term and returns may only be visible in the long run. The authors also comment that customers' willingness to pay for new solutions may not be commensurate with the costs generated.

\subsubsection{Planning Risks}

Although overall industry 4.0 opportunities are already well-documented (Schneider, 2018), there is a lack of deployment standards (Kamble et al., 2018). A strategic policy towards Industry 4.0 is important for its successful implementation (Moktadir et al., 2018) and the wrong solutions can be avoided.

When we address the issue of company size, technology trends have stronger positive relationships in large companies than in SMEs (Müller, Kiel, et al., 2018). The research of (Sommer, 2015), reveals that the smaller a company, the greater its chances of becoming victims rather than beneficiaries. Thus, within a fully connected supply chain through the Industry 4.0 End-to-End integration concept, widening the gap between SMEs and large corporations is uninteresting (Sommer, 2015), as smaller companies may feel pressured and not catch up with the new trends, affecting partners in the top of the chain. Furthermore, in this context of companies' relationships, some of them fear becoming dependent on services offered by suppliers who have expertise in key technologies of the Fourth Industrial Revolution (Müller, Kiel, et al., 2018).

\subsubsection{Market Risks}

When we look at market issues, competition between companies can increase rapidly as industrial boundaries begin to shift in the technological context. Newmarket players from different industries and geographic regions may emerge, facilitated by business boundaries that may disappear due to virtualization (Kusum \& Yinghua, 2018; Xu et al., 2018). Besides, new service-related business models can increase their value creation capacity (Freddi, 2018). Increasingly sought-after customer, personalization is beginning to convert the value chain from the production side to the service side (G. Li et al., 2017), where offering functionality and accessibility beyond tangible product can be a market-leading concept (T Stock \& Seliger, 2016). Any resource, such as production lines, assembly lines, storage, computing, labor, know-how, etc., can be offered through a network (Dai \& Vasarhelyi, 2016), both internally and externally to enterprises boundaries, where other companies may pay for these services (Dai \& Vasarhelyi, 2016).

When it comes to customer relations, companies also need to be aware of the level of the client's participation in product customization. In a context where companies use technologies that enable interventions, the customer will be actively involved in the value creation process of a product. Customers will be able to intervene and adjust specifications not only before ordering but also during design, manufacture, assembly, and testing (G. Li et al., 2017), incorporating lastminute changes also (Pilloni, 2018). Thus, it is important to note to what extent this freedom of intervention can be beneficial to companies. Besides, companies may also face challenges related to convincing customers about the beneficial nature of new technology solutions (Daniel Kiel, Arnold, \& Voigt, 2017), where they will need to better understand which services customers are willing to pay for (Schneider, 2018).

\subsection{Social Risks}

\subsubsection{Human Capital}

The high demand for skilled labor to handle and work with the new concepts and technologies can lead managers to face critical situations due to the possible shortage of professionals with necessary technical skills (G. Li et al., 2017; Moktadir et al., 2018). Thus, finding human talents for the demands of industry 4.0 can be a potential challenge (Tupa, Simota, \& Steiner, 2017). Moreover, employees may be reluctant to changes from the Fourth Industrial Revolution (de Sousa Jabbour, Jabbour, Foropon, \& Filho, 2018). The diffusion of the Industry 4.0 concept should be analyzed to understand how employees depending on the hierarchical level perceive it or to find what fears may arise due to digital changes (Schneider, 2018).

As for employee safety, in an industrial environment proposed by the Fourth Industrial Revolution, humans and machines can interact in difficult and dangerous tasks. As the separation of spaces between humans and robots is removed, established safety procedures can be breached making space for risks of impact between humans and machines (Gobbo, Busso, Gobbo, \& Carreão, 2018). In this context, close human-machine interactions present a wide range of risks that are difficult to predict. Therefore, collaborative robots should be safety conscious and should recognize actions that could cause injury or threaten the safety of employees (Badri, Boudreau-Trudel, \& Souissi, 2018).

Moreover, within a psychological setting, people's ability to adapt to technological change is becoming increasingly 
important, where developing the notion of career adaptability can help in understanding, which psychosocial resources need to handle to succeed in challenges from the increasingly digitized and automated working model (Hirschi, 2018). Changes and interactions in the form and organization of work can be viewed in a negative form and generate psychosocial risks that must be considered (Badri et al., 2018).

\subsubsection{Society}

As with all previous industrial revolutions, there is a risk that the Fourth Industrial Revolution increase social inequality, raise geopolitical tensions, and diminish the well-being of large numbers of people. It is not unlikely that digitalization reproduces the most serious contradictions due to income accumulation: declining employment and rising inequalities (Salento, 2018). Digitalization can increase the pressure on lessskilled workers who will have their jobs threatened. Thus, a smaller portion of the society with higher qualifications can benefit (Caruso, 2018), increasing social and wage (Freddi, 2018) inequality.

Moreover, there is concern that machines and robots can replace human work, not only in repetitive and low-skilled tasks but also in highly complex occupations (Freddi, 2018). However, there are still uncertainties regarding the negative impacts on employability, because while occupations are at risk of disappearing, new occupations may arise (Caruso, 2018; Hirschi, 2018; Salento, 2018).

More broadly, inequalities can also happen between countries. In this case, if the spread of Industry 4.0 does not happen geographically homogeneously, there will be niches of economically and socially favored countries, widening the gap between developed and underdeveloped countries (Bonilla, Silva, da Silva, Gonçalves, \& Sacomano, 2018).

\subsubsection{Ethic and legality}

The use of intelligent and autonomous systems generates important and necessary ethical discussions (Winfield, Michael, Pitt, \& Evers, 2019). A challenge related to Artificial Intelligence, for example, is the accountability of ethical consequences arising from decisions made by machines. In this case, it is discussed to whom the error should be attributed (Taddeo \& Floridi, 2018; Winfield et al., 2019). In addition, technologies can quietly enter our environment and influence our decisions (Taddeo \& Floridi, 2018). Therefore, developing machines that are aware of their actions and the possible harmful consequences is a problem that deserves attention (Winfield et al., 2019). Nevertheless, ethical issues are difficult to attribute to artificial intelligence because related principles vary according to domains of analysis and cultural contexts (Taddeo $\&$ Floridi, 2018) further hampering this issue.

As for data ownership, high equipment connectivity through IoT (Internet of Things) can endanger sensitive user data. Private information may be leaked improperly or without consent (Lee \& Lee, 2015). Privacy and personal security concerns start to emerge from the appropriation of information (Roblek, Meško, \& Krapež, 2016), where, according to, legal issues may be involved. Thus, there is a need for regulations for this scenario (Strange \& Zucchella, 2017; Valente et al., 2018). Moreover, data appropriation can lead to legal and ethical problems regarding the misuse of information (Romero et al., 2018). For example, companies may use personal data to predict the health of an employee in order to base promotion or contract termination (Lee \& Lee, 2015), or a person in total control of knowledge networks in science and society may create social and political power structures in the form of authoritarian governance (Özdemir, 2018).

\subsection{Environment Risks}

\subsubsection{Consumption}

As there will be a need to build a support infrastructure for digital transformation, new machines, sensors, software systems, etc. will be demanded. This massive adoption of technologies will depend on the use of natural or man-made resources for their manufacture, such as water, raw materials, and fuels (Bonilla et al., 2018). Scarce resources on the planet such as lithium and rare earth, which are difficult to extract, manipulate, and purify, may have their demands increased (Bonilla et al., 2018). In addition, there may be an increase in the use of materials and natural resources that are difficult to reuse, where recycling practices are not yet in place or the costs involved may be high. Moreover, the miniaturization of technologies has enabled the use of small quantities of technology metals in their compositions, which makes their recovery difficult and may be lost forever if they are not returned in closed-loop material cycles [].

From an operational perspective, the use of new technologies may require a large amount of energy, becoming a potential challenge (Bonilla et al., 2018; Tim Stock, Obenaus, Kunz, \& Kohl, 2018). Industrial wireless networks that require low latency (X. Li et al., 2017; Pilloni, 2018), cryptographic data security system, and processing large amounts of information (Big Data) in data centers (Tim Stock et al., 2018) may require heavy consumption of this resource (X. Li et al., 2017; Pilloni, 2018).

\subsubsection{Pollution}

An increase in the electronic waste can be expected in the context of Industry 4.0. Machines or equipment may be replaced because they cannot be integrated into new digital systems and environments (Bonilla et al., 2018). Thus, recycling and reuse of obsolete equipment can become a recurring issue.

In the high-consumption scenario, the increase in primary energy use can trigger growth in $\mathrm{CO} 2$ and greenhouse gas emissions (Moktadir et al., 2018; Tim Stock et al., 2018). These emissions may also occur in the consumption of fuels to manufacture new equipment and technologies, or even, in distribution logistics and transportation of obsolete materials for disposal or recycling (Bonilla et al., 2018).

\subsection{Technological Risks}

\subsubsection{Technical Risks}

The Industrial Internet of Things (IIoT) will enable the integration of a large number of devices and coexisting nearby. This dense layer of devices can lead to an unprecedented number of interferences between them (Sisinni, Saifullah, Han, Jennehag, \& Gidlund, 2018). Industrial Wireless Network, for example, can face major challenges due to the multiple signals in connected environments. Besides, the industrial environment is characterized by challenging signal transfer conditions, such 
as dust, vibration, critical temperatures, humidity, motor presence, metal obstacles, etc. (X. Li et al., 2017).

The internet network may also face overload challenges. Real-time control and access, a major issue within the context of Industry 4.0, requires bandwidth to be fast and unloaded. A delay in data transfer, for example, can create problems for connected physical devices (Khan, Wu, Xu, \& Dou, 2017).

Another problem regarding high connectivity is the lack of interoperability. Industrial networks based on industry 4.0 concepts will be highly heterogeneous, as they will feature several interconnected technologies such as machines, sensors, Cyber-Physical Systems (CPS), IoT devices, etc. (Khan et al., 2017). Thus, a barrier to the adoption of IoT solutions and the creation of a CPS ecosystem is the establishment of integration and continuous interoperability between these different technologies and systems (Kamble et al., 2018). Many installations may contain machines and equipment, where each one has a different format for communicating with other machines (Gao et al., 2015). The lack of interoperability between devices will significantly increase the complexity and cost of deploying technologies (Sisinni et al., 2018).

Hyperconnectivity can also lead to systems becoming fragile in interruptions events, where an error in one part of the system may cause general disorder (Lee \& Lee, 2015) as in a domino effect (Özdemir, 2018).

\subsubsection{Data Security}

One of the most commented risks in the literature is related to data security. IT integrations and production digitization can create a potential danger (Tupa et al., 2017), both in vertical and internal business connections as well as horizontal connections across entire value chains (D Kiel et al., 2017). As for connectivity increases due to technologies, industrial systems are becoming increasingly susceptible and vulnerable to cyberattacks (Jansen \& Jeschke, 2018; Kamble et al., 2018; Lee \& Lee, 2015; Özdemir, 2018; Strange \& Zucchella, 2017). A large amount of heterogeneous data and its transfer to the cloud increases the security risk (Khan et al., 2017) because wireless networks can be easily intercepted also (Pilloni, 2018) as well as the open connection between participants in a value chain (D Kiel et al., 2017). The most diverse damage may be caused: machine scrapping, defective products (Wu, Song, \& Moon, 2019), service interruptions, operator safety can be threatened (Gao et al., 2015), etc.

Data vulnerability may also lead to the disclosure of private data. Companies should be aware that sensitive data may be disclosed (Tuptuk \& Hailes, 2018). In the absence of appropriate security mechanisms, private information leakage is inevitable. Not only internal business data but also information from connected partners may be in danger (Müller, Buliga, et al., 2018).

\subsubsection{Data Handling}

The big amount of data (Big Data) in different formats are also a challenge for information acquisition, transformation (Khan et al., 2017), storage, and analysis (He et al., 2016). Knowing which data should be collected, how this data should be collected, and how to formulate it are important points to study. In this context, the processing and analysis of heterogeneous information may be hampered by the lack of unified format solutions such as standardized IoT architectures (Wan et al., 2016).

Besides, data quality may also become a challenge (X. Li et al., 2017). The large amount of data generated can make it difficult to obtain useful information (X. Li et al., 2017). The vast majority of data from intelligent manufacturing is unstructured, which must be transformed into structured data so that barriers due to source, shape, size, and other factors are eliminated and useful information can be extracted (Yan, Meng, $\mathrm{Lu}, \& \mathrm{Li}, 2017$ ). Thus, in the context of Industry 4.0, it is easy to obtain incomplete and deficient data due to transport failure, data limitations, and errors or packet loss, especially in large scale industrial networks (X. Li et al., 2017).

\subsection{Regulation Aspects}

Besides all economic, social, ecological, and technological aspects, regulatory and legal issues involved in business digitalization should be discussed as they may support the benefits. According to (Salento, 2018), national and supranational institutions are expected to adjust economic regulation to provide a facilitating framework for new digital trends.

When it comes to cybersecurity, there are no specific standards in manufacturing, let alone intelligent manufacturing (Tuptuk \& Hailes, 2018). There is a need for regulations due to potential cyber risks and implications for the privacy of individuals (Strange \& Zucchella, 2017), where the absence of effective standards and regulations coupled with weak governance limit the functioning of IoT.

From a social perspective, worker safety, health, and physical integrity regulations may be set late due to laws, regulations, and standards arising reactively. In addition, standards must suit changes driven by technological innovations where old rules do not apply (Badri et al., 2018). Moreover, the regulation involved in the use of artificial intelligence is still a necessary task (Taddeo \& Floridi, 2018).

Regarding the environment, within the portfolio studied, there are few studies on the negative environmental impact of Industry 4.0, which may lead to unexpected problems for this field of knowledge, in which regulations may be involved.

Thus, inaccurate regulations can affect all of the risk dimensions discussed in this paper, thereby increasing the need for standards to help manage and mitigate uncertainties in Industry 4.0 implementation. According to (Tuptuk \& Hailes, 2018), although standards are not regulations, regulators can dictate compliances from a standard in such a way that it becomes part of a regulation.

\section{THEORETICAL FRAMEWORK}

From the discussions of risks arising from the implementation of Industry 4.0 concepts and technologies, it is possible to perceive certain relationships between the dimensions due to some risks that may have effects between them. For example, the lack of interoperability between machines, despite being characterized as technological risk, can also affect the economic sustainability of companies, increasing the cost of implementing new technologies. Another example is the question that the successful implementation of Industry 4.0 depends on skilled professionals (Moktadir et al., 2018), where investments in skilled labor will be required. Also, employee 
resistance to change may affect the technology transition to Industry 4.0 (de Sousa Jabbour et al., 2018). We can also see a relationship between environmental and economic issues, where the environmental risk related to the consumption of natural resources may entail the use of materials that are difficult to reuse and the recycling costs may be high (Tim Stock et al., 2018).

In general, technological risks are closely related to economic issues, as misused technologies or technological difficulties may lead to reduced productivity or require correction costs. For example, some technologies may increase exposure to external risks, where a non-localized disruption in a supply chain may affect the performance of the entire chain in a ripple effect (Ivanov, Dolgui, \& Sokolov, 2019).

Therefore, a framework is built to represent the relationships between the risk dimensions described in this paper. For this, based on the Triple Bottom Line theory, Elkington's three dimensions (economic, social, and environmental) receive a dimensional addition where four ellipses are intertwined (Figure 3). Also, as it has been found that there is a need for precise regulations for the 4.0 industry context, the regulatory issue will be illustrated as a support base for all dimensions.

\section{CONCLUSIONS}

The presented study discusses the main risks identified in the literature regarding the implementation of Industry 4.0 concepts and technologies from a sustainability perspective. Elkington's three dimensions (economic, social, and environmental) together with a proposed fourth dimension are used to group the risks encountered. More economic, social, and technological risks were verified and environmental risks are still little discussed in the literature. In addition, regulatory and standardization issues are presented as important points for this rising theme.

The built theoretical framework demonstrates the risks found in a general way and the relationships between the proposed dimensions. Besides, this framework can be used for future risk analysis and categorization that may still arise, as the theme is recent and many challenges have not yet been mapped.

This work, besides contributing to academia in the development of theoretical constructions for the theme, can also help managers and companies to check important points before starting their journey in the Fourth Industrial Revolution. Furthermore, public agencies can be alerted to issues of inequality, unemployment, and regulations.

Social Risks

- Lack of skilled labor

- Reluctance to changes

- Risk to the physical integrity of employees

- Psychosocial issues

- Increasing inequalities and social tensions

- Job losses

- Artificial Intelligence ethical issues

- Privacy invasion

Technological Risks

- Signal Interference

- Network technical inability

- Lack of interoperability

- Technological Chaos

- Cyber attacks

- Disclosure of private data

- Ineffective Data Analysis

- Low data quality

\section{Environmental Risks}

- Increased consumption of natural resources

- High energy consumption

- Electronic Waste

- Emission risk

Economic Risks

- High deployment costs

- Uncertain financial return

- Implementation inaccuracy

- Self-sabotage over a value chain

- Partners Dependency

- Increased competition

- Negative customer interventions

- Customer acceptance difficulty

\section{Legend}

Social Risks Dimension (SORD)

Technological Risks Dimension (TERD)

Environmental Risks Dimension(ENRD)

Econom ic Risks Dimension (ECRD)

Figure 3 - Theoretical framework for the effects of industry risks 4.0 
The limitations of the study refer to the use of only two databases and only the literature for risk assessment. Thus, practical studies focused on interviews with experts can be performed. Moreover, more relationships between the mapped rich can be made in the form of quantitative analyzes.

\section{R E F E R E N C E S}

AHUETT-GARZA，H., \& KURFESS, T. (2018). A brief discussion on the trends of habilitating technologies for Industry 4.0 and Smart manufacturing. Manufacturing Letters, 15 ,

$60-63$. https://doi.org/10.1016/j.mfglet.2018.02.011

BADRI, A., BOUDREAU-TRUDEL, B., \& SOUISSI, A. S. (2018). Occupational health and safety in the industry 4.0 era: A cause for major concern? Safety Science, 109, 403-411. https://doi.org/10.1016/j.ssci.2018.06.012

BAHRIN, M. A. K., OTHMAN, M. F., AZLI, N. H. N., \& TALIB, M. F. (2016). Industry 4.0: A review on industrial automation and robotic. Jurnal Teknologi, 78(6-13), 137-143. https://doi.org/10.11113/jt.v78.9285

BARRETO, L., AMARAL, A., \& PEREIRA, T. (2017). Industry 4.0 implications in logistics: an overview. Procedia Manufacturing, 13, 1245-1252. https://doi.org/https://doi.org/10.1016/j.promfg.2017.09. 045

BONILlA, S. H., SILVA, H. R. O., DA SILVA, M. T., GONÇALVES, R. F., \& SACOMANO, J. B. (2018). Industry 4.0 and sustainability implications: A scenariobased analysis of the impacts and challenges. $\begin{array}{lll}\text { Sustainability } \quad \text { (Switzerland), } & \text { 10(10). }\end{array}$ https://doi.org/10.3390/su10103740

CARUSO, L. (2018). Digital innovation and the fourth industrial revolution: epochal social changes? AI and Society, 33(3), 379-392. https://doi.org/10.1007/s00146-017-0736-1

DAI, J., \& VASARHELYI, M. A. (2016). Imagineering Audit 4.0. Journal of Emerging Technologies in Accounting, $13(1), 1-15$.

DE SOUSA JABBOUR, A. B. L., JABBOUR, C. J. C., FOROPON, C., \& FILHO, M. G. (2018). When titans meet - Can industry 4.0 revolutionise the environmentally-sustainable manufacturing wave? The role of critical success factors. Technological Forecasting and Social Change, 132, 18-25. https://doi.org/10.1016/j.techfore.2018.01.017

FOIDL, H., \& FELDERER, M. (2015). Research challenges of industry 4.0 for quality management. International Conference on Enterprise Resource Planning Systems, 121-137. Springer.

FREDDI, D. (2018). Digitalisation and employment in manufacturing. AI \& SOCIETY, 33(3, SI), 393-403. https://doi.org/10.1007/s00146-017-0740-5

GAO, R., WANG, L., TETI, R., DORNFELD, D., KUMARA, S., MORI, M., \& HELU, M. (2015). Cloud-enabled prognosis for manufacturing. CIRP Annals, 64(2), 749772.

GOBBO, J. A., BUSSO, C. M., GOBBO, S. C. O., \& CARREÃO, H. (2018). Making the links among environmental protection, process safety, and industry 4.0. Process Safety and Environmental Protection, 117, 372-382. https://doi.org/https://doi.org/10.1016/j.psep.2018.05.01 7

HE, H., MAPLE, C., WATSON, T., TIWARI, A., MEHNEN, J., JIN, Y., \& GABRYS, B. (2016). The security challenges in the IoT enabled cyber-physical systems and opportunities for evolutionary computing \& other computational intelligence. 2016 IEEE Congress on Evolutionary Computation, CEC 2016, 1015-1021. https://doi.org/10.1109/CEC.2016.7743900

HIRSCHI, A. (2018). The Fourth Industrial Revolution: Issues and Implications for Career Research and Practice. Career Development Quarterly, 66(3), 192-204. https://doi.org/10.1002/cdq.12142

IMRAN, F., \& KANTOLA, J. (2018). Review of industry 4.0 in the light of sociotechnical system theory and competence-based view: A future research agenda for the evolute approach. International Conference on Applied Human Factors and Ergonomics, 118-128. Springer.

IVANOV, D., DOLGUI, A., \& SOKOLOV, B. (2019). The impact of digital technology and Industry 4.0 on the ripple effect and supply chain risk analytics. International Journal of Production Research, 57(3), 829-846. https://doi.org/10.1080/00207543.2018.1488086

JANSEN, C., \& JESCHKE, S. (2018). Mitigating risks of digitalization through managed industrial security services. AI and Society, 33(2), 163-173. https://doi.org/10.1007/s00146-018-0812-1

KAGERMANN, H., WAHLSTER, W., \& HELBIG, J. (2013). Acatech-National Academy of Science and Engineering. Recommendations for Implementing the Strategic Initiative INDUSTRIE, 4.

KAMBLE, S. S., GUNASEKARAN, A., \& SHARMA, R. (2018). Analysis of the driving and dependence power of barriers to adopt industry 4.0 in Indian manufacturing industry. Computers in Industry, 101, 107-119. https://doi.org/10.1016/j.compind.2018.06.004

KHAN, M., WU, X., XU, X., \& DOU, W. (2017). Big Data Challenges and Opportunities in the Hype of Industry 4.0. 2017 IEEE INTERNATIONAL CONFERENCE ON COMMUNICATIONS (ICC).

KIEL, D, MÜllER, J. M., ARNOLD, C., \& VOIGT, K.-I. (2017). Sustainable industrial value creation: Benefits and challenges of industry 4.0. International Journal of Innovation Management, 21(8). https://doi.org/10.1142/S1363919617400151

KIEL, DANIEL, ARNOLD, C., \& VOIGT, K.-I. (2017). The influence of the Industrial Internet of Things on business models of established manufacturing companies - A business level perspective. TECHNOVATION, 68, 419. https://doi.org/10.1016/j.technovation.2017.09.003

KUSUM, P. P. A., \& YINGHUA, S. (2018). HOW DO ENTREPRENEURS'PERCEPTIONS ON INNOVATION EFFECT ININDUSTRY COMPETITIVENESS AND SUSTAINABILITY. Journal on Innovation and Sustainability, 9(2), 12-19.

LASI, H., FETTKE, P., KEMPER, H.-G., FELD, T., \& HOFFMANN, M. (2014). Industry 4.0. Business \& Information Systems Engineering, 6(4), 239-242.

LEE, I., \& LEE, K. (2015). The Internet of Things (IoT): Applications, investments, and challenges for enterprises. Business Horizons, 58(4), 431-440.

LI, G., HOU, Y., \& WU, A. (2017). Fourth Industrial Revolution: technological drivers, impacts and coping 
methods. Chinese Geographical Science, 27(4), 626637. https://doi.org/10.1007/s11769-017-0890-x

LI, X., LI, D., WAN, J., VASILAKOS, A. V, LAI, C.-F., \& WANG, S. (2017). A review of industrial wireless networks in the context of Industry 4.0. Wireless Networks, 23(1), 23-41. https://doi.org/10.1007/s11276015-1133-7

LIAO, Y., LOURES, E. R., DESCHAMPS, F., BREZINSKI, G., \& VENÂNCIO, A. (2018). The impact of the fourth industrial revolution: A cross-country/region comparison. Producao, 28. https://doi.org/10.1590/01036513.20180061

LUTHRA, S., \& MANGLA, S. K. (2018). Evaluating challenges to Industry 4.0 initiatives for supply chain sustainability in emerging economies. Process Safety and Environmental Protection, 117, 168-179. https://doi.org/10.1016/j.psep.2018.04.018

MOKTADIR, M. A., ALI, S. M., KUSI-SARPONG, S., \& SHAIKH, M. A. A. (2018). Assessing challenges for implementing Industry 4.0: Implications for process safety and environmental protection. Process Safety and Environmental Protection, 117, 730-741. https://doi.org/10.1016/j.psep.2018.04.020

MÜLLER, J. M., BULIGA, O., \& VOIGT, K.-I. (2018). Fortune favors the prepared: How SMEs approach business model innovations in Industry 4.0. Technological Forecasting and Social Change, 132, 2-17. https://doi.org/10.1016/j.techfore.2017.12.019

MÜLLER, J. M., KIEL, D., \& VOIGT, K.-I. (2018). What drives the implementation of Industry 4.0? The role of opportunities and challenges in the context of sustainability. Sustainability (Switzerland), 10(1). https://doi.org/10.3390/su10010247

ÖZDEMIR, V. (2018). The dark side of the moon: The internet of things, industry 4.0 , and the quantified planet. OMICS A Journal of Integrative Biology, 22(10), 637-641. https://doi.org/10.1089/omi.2018.0143

PAGANI, R. N., KOVALESKI, J. L., \& RESENDE, L. M. (2015). Methodi Ordinatio: a proposed methodology to select and rank relevant scientific papers encompassing the impact factor, number of citation, and year of publication. Scientometrics, 105(3), 2109-2135.

PFEIFFER, S. (2017). The Vision of "Industrie 4.0" in the Making - a Case of Future Told, Tamed, and Traded. NanoEthics, 11(1), 107-121. https://doi.org/10.1007/s11569-016-0280-3

PICCAROZZI, M., AQUILANI, B., \& GATTI, C. (2018). Industry 4.0 in management studies: A systematic literature review. Sustainability (Switzerland), 10(10). https://doi.org/10.3390/su10103821

PILLONI, V. (2018). How data will transform industrial processes: Crowdsensing, crowdsourcing and big data as pillars of industry 4.0. Future Internet, 10(4). https://doi.org/10.3390/fi10030024

PREUVENEERS, D., \& ILIE-ZUDOR, E. (2017). The intelligent industry of the future: A survey on emerging trends, research challenges and opportunities in Industry 4.0. Journal of Ambient Intelligence and Smart Environments, 9(3), 287-298. https://doi.org/10.3233/AIS-170432

ROBLEK, V., MEŠKO, M., \& KRAPEŽ, A. (2016). A Complex View of Industry 4.0. SAGE Open, 6(2). https://doi.org/10.1177/2158244016653987
ROMERO, D., MATTSSON, S., FAST-BERGLUND, ̊., WUEST, T., GORECKY, D., \& STAHRE, J. (2018). Digitalizing occupational health, safety and productivity for the operator 4.0 (K. D., M. I., P. J., von C. G., \& L. G.M., Eds.). IFIP WG 5.7 International Conference on Advances in Production Management Systems, APMS 2018, Vol. 536, pp. 473-481. https://doi.org/10.1007/978-3-319-99707-0_59

SALENTO, A. (2018). Digitalisation and the regulation of work: theoretical issues and normative challenges. AI and Society, 33(3), 369-378. https://doi.org/10.1007/s00146-017-0738-z

SCHNEIDER, P. (2018). Managerial challenges of Industry 4.0: an empirically backed research agenda for a nascent field. Review of Managerial Science, 12(3), 803-848. https://doi.org/10.1007/s11846-018-0283-2

SISINNI, E., SAIFULLAH, A., HAN, S., JENNEHAG, U., \& GIDLUND, M. (2018). Industrial Internet of Things: Challenges, Opportunities, and Directions. IEEE TRANSACTIONS ON INDUSTRIAL INFORMATICS, 14(11), 4724-4734. https://doi.org/10.1109/TII.2018.2852491

SOMMER, L. (2015). Industrial revolution - Industry 4.0: Are German manufacturing SMEs the first victims of this revolution? Journal of Industrial Engineering and Management, $8(5)$, https://doi.org/10.3926/jiem.1470

STOCK, T, \& SELIGER, G. (2016). Opportunities of Sustainable Manufacturing in Industry 4.0. Procedia CIRP, 40, 536-541. https://doi.org/https://doi.org/10.1016/j.procir.2016.01.1 29

STOCK, TIM, OBENAUS, M., KUNZ, S., \& KOHL, H. (2018). Industry 4.0 as enabler for a sustainable development: A qualitative assessment of its ecological and social potential. Process Safety and Environmental Protection, 118 ,

254-267. https://doi.org/https://doi.org/10.1016/j.psep.2018.06.02 6

STRANGE, R., \& ZUCCHELLA, A. (2017). Industry 4.0, global value chains and international business. Multinational Business Review, 25(3), 174-184. https://doi.org/10.1108/MBR-05-2017-0028

TADDEO, M., \& FLORIDI, L. (2018). How AI can be a force for good. Science, 361(6404), 751-752.

TUPA, J., SIMOTA, J., \& STEINER, F. (2017). Aspects of Risk Management Implementation for Industry 4.0. Procedia Manufacturing, 11, 1223-1230. https://doi.org/10.1016/j.promfg.2017.07.248

TUPTUK, N., \& HAILES, S. (2018). Security of smart manufacturing systems. Journal of Manufacturing Systems, $47, \quad 93-106$. https://doi.org/https://doi.org/10.1016/j.jmsy.2018.04.00 7

VAlEnte, B. C., COTRIM, S. L., GASQUES, A. C. F., LEAL, G. C. L., \& GALDAMEZ, E. V. C. (2018). Sustainability indicators in industries: A bibliometric review. Journal on Innovation and Sustainability RISUS, 9(3), 38-52.

WAN, J., TANG, S., SHU, Z., LI, D., WANG, S., IMRAN, M., \& VASILAKOS, A. V. (2016). Software-Defined Industrial Internet of Things in the Context of Industry 
4.0. IEEE Sensors Journal, 16(20), 7373-7380. https://doi.org/10.1109/JSEN.2016.2565621

WINFIELD, A. F., MICHAEL, K., PITT, J., \& EVERS, V. (2019). Machine ethics: The design and governance of ethical ai and autonomous systems. Proceedings of the IEEE, 107(3), 509-517. https://doi.org/10.1109/JPROC.2019.2900622

WU, M., SONG, Z., \& MOON, Y. B. (2019). Detecting cyberphysical attacks in CyberManufacturing systems with machine learning methods. Journal of Intelligent Manufacturing, 30(3), 1111-1123.

XU, L. D., XU, E. L., \& LI, L. (2018). Industry 4.0: State of the art and future trends. International Journal of Production Research, 56(8), 2941-2962. https://doi.org/10.1080/00207543.2018.1444806

YAN, J., MENG, Y., LU, L., \& LI, L. (2017). Industrial Big Data in an Industry 4.0 Environment: Challenges, Schemes, and Applications for Predictive Maintenance. IEEE Access, 5, 23484-23491. https://doi.org/10.1109/ACCESS.2017.2765544

ZHENG, P., WANG, H., SANG, Z., ZHONG, R. Y., LIU, Y., LIU, C., ... XU, X. (2018). Smart manufacturing systems for Industry 4.0: Conceptual framework, scenarios, and future perspectives. Frontiers of Mechanical Engineering, 13(2), 137-150. https://doi.org/10.1007/s11465-018-0499-5 